\title{
The release of soluble forms of TRAIL and DR5 by neutrophils of oral cavity cancer patients
}

\author{
Ewa Jablonska' ${ }^{1}$ Jakub Jablonski², Magdalena Marcinczyk ${ }^{1}$, Zyta Grabowska ${ }^{3}$, \\ Leszek Piotrowski ${ }^{3}$
}

${ }^{1}$ Department of Immunology, ${ }^{2}$ Department of Toxicology, ${ }^{3}$ Department of Oral and Maxillofacial Surgery, Medical University of Bialystok, Poland

\begin{abstract}
In the present study we examined the release of the soluble form of TRAIL by neutrophils (PMN) derived from patients with oral cavity cancer. Simultaneously, we estimated the ability of PMNs of these patients to release the soluble form of DR5 receptor, a natural regulatory protein of TRAIL. The obtained results were confronted with the serum levels of sTRAIL and sDR5. The cells were isolated from 21 patients with squamous cell carcinoma of oral cavity at diagnosis and three weeks after surgery treatment. For comparative purposes we performed similar examinations in autologous peripheral blood mononuclear cells (PBMC). Cytoplasmic protein fractions of the cells were analyzed for the presence of TRAIL and DR5 by western blotting. Soluble TRAIL and soluble DR5 concentrations in the culture supernatants of cells were confronted with their serum levels using ELISA kit. PMN and PBMC of the whole cancer patient group expressed decreased TRAIL protein and unchanged expression of DR5 receptor in comparison with the control group. Unchanged release of sTRAIL by PMNs of patients in Stage II was accompanying the decrease of the ability of PBMC to secrete this protein. In patients in Stage IV the secretion of sTRAIL by PMNs and PBMC was impaired. In contrast to changes in sTRAIL secretion by PMN and PBMC of oral cavity cancer patients, the secretion of sDR5 by these cells was unchanged. The serum levels of sTRAIL were increased in patients in Stage II before treatment and decreased in the same patients after treatment. The altered ability of PMN of PBMC to secrete sTRAIL may have different implications for the immune response of patients with oral cavity cancer cells at different stages of disease.
\end{abstract}

Key words: Neutrophils - Peripheral blood mononuclear cells - (TNF)-related apoptosis-inducing ligand - DR5 receptor Oral cavity cancer

\section{Introduction}

Human polymorphonuclear neutrophils (PMNs) have been postulated to have both beneficial and detrimental roles in the immune response to various tumors $[1,2]$. The classical antitumor effect of the neutrophils includes the antibody-dependent cell cytotoxic, the directed cell killing by reactive oxygen species, as well as calprotectin [2]. Furthermore, PMNs can play a role in cytokineinduced tumor rejection, in cooperation with $\mathrm{CD} 8+\mathrm{T}$ lymphocytes [2]. It was well established that human PMNs synthesize and secrete cytokines that influence the different effector cells recruitment and modulation within the tumor microenvironment $[1,3]$.

Correspondence: E. Jablonska, Dept. of Immunology, Medical University of Bialystok, Waszyngtona Str. 15A,

15-274 Bialystok, Poland; tel.: (+4885) 7450546,

fax: (+4885) 7450588, e-mail: ewaj@amb.edu.pl
Neutrophils are known to produce ligands of the TNF family, such as TNF- $\alpha$, Fas ligand, CD30 ligand, B-lymphocyte stimulator (BLyS) and tumor necrosis factor (TNF)-related apoptosis-inducing ligand (TRAIL) [1,4-6]. In contrast to other members of the TNF superfamily, whose expression is tightly regulated and which are often only transiently expressed on activated cells, TRAIL is expressed constitutively in a wide range of cells, involving neutrophils $[6,7]$.

TRAIL (Apo-2L) is a type II transmembrane protein that was originally identified and cloned on the basis of sequence homology to the Fas ligand and TNF [7-9]. Endogenous TRAIL can be biologically effective not only as an integral membrane protein but also as a soluble cytokine which is released by human neutrophils $[4,6,7]$.

TRAIL and sTRAIL can selectively induce apoptosis in a number of cell types, including many transformed and tumor cells [7-10]. It is interesting to note 
that most normal cells are not sensitive to TRAILmediated apoptosis $[8,9]$.

TRAIL exerts its biological activity by interacting with a complex system of two death receptors TRAILR1(DR4) and TRAIL-R2(DR5), and three "decoy receptors" TRAIL-R3(DcR1), TRAIL-R4(DcR2), as well as osteoprotegerin (OPG). TRAIL-R1 and TRAIL-R2 containing cytoplasmic "death domains" signal apoptosis [7-10]. TRAIL-R4 has a truncated, non-functional cytoplasmic death domain, while TRAIL-R3 lacks a cytosolic region and is anchored to the plasma membrane. Both receptors are therefore incapable of transmitting an apoptosis signal [9]. OPG is a soluble receptor for TRAIL, and may also act as a soluble decoy receptor [11].

The TRAIL receptors expression were found in human neutrophils. Kamohara et al. reported that neutrophils express death receptor DR5 and "decoy receptor" DcR1 [4]. The extracellular domains of DR5 and DcR1 are expressed in a soluble, monomeric form $[12,13]$. Soluble DR5 receptor (sDR5) is able to bind TRAIL and to modulate TRAIL-mediated reactions [14]. For example, Myashita et al. demonstrated that soluble DR5 receptor significantly inhibits TRAILinduced apoptosis [13].

The preferential activity of TRAIL against cancer cells has generated hopes for its potential use in cancer therapy as a single remedy or in combination with chemotherapy and radiotherapy $[8,15]$. For example, it was observed that the combination of cisplatin and TRAIL resulted in synergistic induction of cell death in head and neck squamous cell carcinoma - 6 (HNSCC-6) and HNSCC-30 cells [15]. Recent data of Teng et al. demonstrated that HNSCC tumor cells express TRAIL-R1 and TRAIL-R2 that make them sensitive to TRAIL-mediated apoptosis induced by different cells [16].

On the basis of the above findings, we examined the release of the soluble form of TRAIL by neutrophils derived from patients with oral cavity cancer. Simultaneously, we estimated the ability of PMNs of this patients to the release soluble form of DR5 receptor, a natural regulatory protein of TRAIL. Examinations above can be helpful in the evaluation a potential role of neutrophils in TRAIL-mediated reactions in patients with oral cavity cancer.

\section{Materials and methods}

Sample material. 20 patients, aged from 45 to 49 years, with squamous cell carcinoma of oral cavity treated in the Department of Oral and Maxillofacial Surgery, Medical University of Bialystok were examined. Examinations were carried out on patients before the treatment and 3 weeks after the surgical removal of the tumor mass. Patients did not receive any treatment or medication before examination. Study results were analyzed taking into account a clinical course of disease according to TNM staging classification [17]. There were no clinical signs of infection observed in patients.
In all patients no significant leukocytosis was observed. The mean number of white cells in the blood of all patients before treatment was $6.183 / \mu \mathrm{L}$ (from 3.8 to $8.95^{3} / \mu \mathrm{L}$ ), after treatment was $5.6^{3} / \mathrm{mL}$ (from 4.0 to $8.25^{3} / \mathrm{mL}$ ). Control subjects $(\mathrm{n}=15)$ were healthy people aged from 30 to 53 years (mean 41.5 year).

Preparation of human neutrophils (PMN) and peripheral blood mononuclear cells (PBMC). For comparative purposes we performed examinations in autologous peripheral blood mononuclear cells (PBMC).

PMNs and PBMC were isolated from whole blood treated with EDTA by density centrifugation using Polymorphoprep (AxisShield, Oslo, Norway) (density - $1.113 \mathrm{~g} / \mathrm{mL}$ ). Five $\mathrm{mL}$ of whole blood were layered on $5 \mathrm{~mL}$ of Polymorphoprep in a 12-mL tube and centrifuged at $500 \times \mathrm{g}$ for $30 \mathrm{~min}$ at room temperature. The neutrophils in the lower band and mononuclear cells in the higher band were harvested using a Pasteur pipette and washed with PBS. Neutrophils were suspended in RPMI 1640 medium (Invitrogen, Carlsbad, CA) and mononuclear cells in Hanks solution to provide $5 \times 10^{6}$ cells $/ \mathrm{mL}$. The purity of isolated PMNs and PBMC was determined by May-Grunewald-Giemsa-staining. The viability of PMNs and PBMC measured using FITC-conjugated annexinV and propidium iodide (PI) (Apotest-FITC, DakoCytomation, Denmark) after isolation was $>98 \%$. The fluorescence intensity of cells was measured using EPICS XL (Beckman Coulter Epics XLMCL).

Culture of PMN and PBMC. The cells in the culture medium containing $10 \%$ autologous serum, $10 \mathrm{U} / \mathrm{mL}$ penicillin and 50 $\mathrm{ng} / \mathrm{mL}$ streptomycin were incubated in flat-bottomed 96-well plates (Microtest III-Falcon, Franklin Lakes, USA) for $20 \mathrm{~h}$ at $37^{\circ} \mathrm{C}$ in a humidified incubator with $5 \% \mathrm{CO}_{2}$ (NUAIRETN). The viability of PMNs measured after $20 \mathrm{~h}$ incubation was $>94 \%$, PBMC was $>95 \%$.

Western blot analysis. After incubation, cells were washed twice with cold phosphate buffered saline (PBS) to remove excess proteins. Cells were lysed directly in the presence of inhibitor protease (Sigma-Aldrich, CHEMIE GmbH P.O. Steinheim, Germany) by sonication using Vibra-Cell Ultrasonic Processor (Sonics\&Materials, Inc., USA). After that the remaining cell debris was removed by centrifugation at $10000 \times \mathrm{g}$ for $15 \mathrm{~min}$ at room temperature and supernatants were collected and stored in $-70^{\circ} \mathrm{C}$.

The amount of protein was determined using the Lowry method and the absorbance was measured in a Beckman DU® 640 at $750 \mathrm{~nm}$. Each lane was loaded with $100 \mu \mathrm{g}$ of protein, and Western blot was performed as described.

Cytoplasmic protein fractions of PMN and PBMC were analyzed for the presence of TRAIL and DR5 proteins by western blotting. Protein fractions were suspended in Laemmli buffer (BioRad Laboratories, Herkules CA, USA) and than were electrophorezed on SDS-PAGE. The resolved protein was transferred onto $0.2 \mu \mathrm{m}$ pore-sized nitrocellulose (Bio-Rad Laboratories, Herkules CA, USA). The nitrocellulose was incubated at $+4^{\circ} \mathrm{C}$ for $18 \mathrm{~h}$ with the primary polyclonal antibodies anti-TRAIL or antiDR5, respectively (Alexis, Carlsbad CA, USA). After washing with $0,1 \%$ TBS-T, the membrane was incubated at room temperature for $1 \mathrm{~h}$ with alkaline phosphatase anti-mouse IgG Abs (Vector Laboratories, Burlingame, CA, USA). Immunoreactive protein bands were visualized following the addition of BCIP/NBT Liquid Substrate System (Sigma-Aldrich, CHEMIE GmbH P.O. Steinheim, Germany).

The measurement of soluble TRAIL and DR5 concentrations. Soluble TRAIL and DR5 levels in the culture supernatants of PMN and PBMC were confronted with their serum levels. Soluble TRAIL concentration was assessed using ELISA kit (R\&D Sys- 


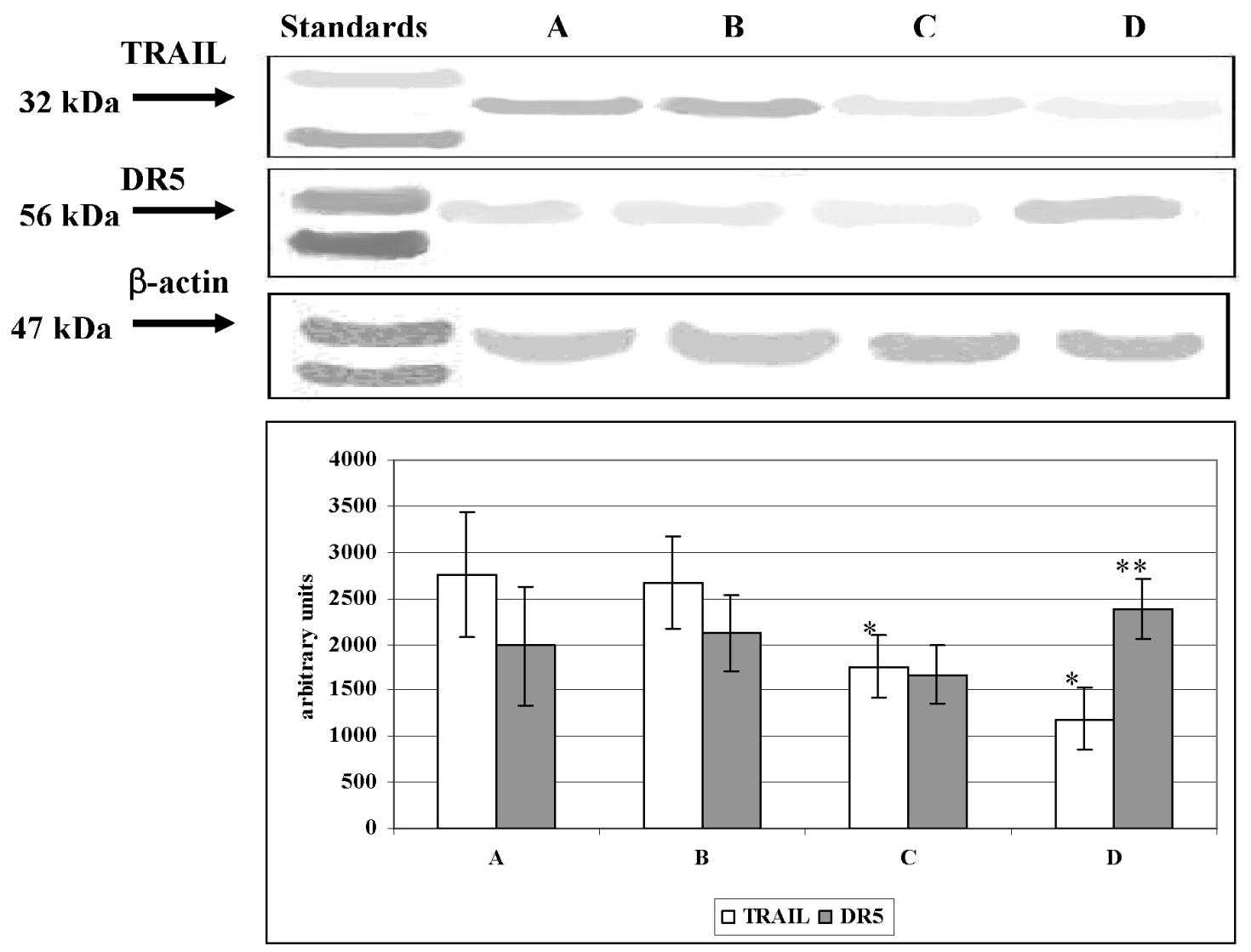

Fig. 1. Western blot analysis of TRAIL and DR5 in PMN and PBMC cells from control and patients with oral cavity cancer before treatment. A: PMN of control; B: PBMC of control; C: PMN of cancer patients; D: PBMC of cancer patients. Representative of a few independent experiments are shown. The diagrams are shown statistical analysis of Western blot of TRAIL and DR5 estimated by arbitrary units. *statistical difference with control $(\mathrm{p}<0.05)$; **statistical difference between PMN and PBMC $(\mathrm{p}<0.05)$.

tems, Minneapolis, USA). A monoclonal antibody specific for human TRAIL has been pre-coated onto a microplate. One hundred $\mu \mathrm{L}$ of Assay Diluent RD1S and $50 \mu \mathrm{L}$ standand, control and sample were added to the wells and incubated for $2 \mathrm{~h}$ at room temperature on a horizontal orbital microplate shaker set at $500 \mathrm{rpm}$. After washing, $200 \mu \mathrm{L}$ Conjugate was added to the wells, incubated $2 \mathrm{~h}$ on the shaker, washed four times. Next, a substrat solution for peroxidase was added to induce a colored reaction and incubated $30 \mathrm{~min}$. The color development was stopped and the intensity of the color was determined by reading absorbance at $540 \mathrm{~nm}$ on a microplate reader UVM340 (ASYS, HITECH, G.m.b.H).

Soluble DR5 concentration was assessed using ELISA kit (BioSource Int., USA). A monoclonal antibody specific for human DR5 has been pre-coated onto a wells of the microplate. One hundred $\mu \mathrm{L}$ of Standard Diluent Buffer to zero wells and $100 \mu \mathrm{L}$ of standards and samples were added to the appropriate wells and incubated for $2 \mathrm{~h}$ at room temperature. After washing four times, $100 \mu \mathrm{L}$ of Conjugate was added to the wells, incubated $1 \mathrm{~h}$, washed four times. Next, $100 \mu \mathrm{L}$ of Streptavidin-HRP Working Solution was added to the wells and incubated $30 \mathrm{~min}$.. After washing, 100 $\mu \mathrm{L}$ of Stabilized Chromogen was added to the wells and incubated $30 \mathrm{~min}$. The color development was stopped and the intensity of the color was determined by reading absorbance at $450 \mathrm{~nm}$ on the microplate reader UVM340 (ASYS, HITECH, G.m.b.H).

Ethical issues. The study was approved by the Ethics Committee of the Medical University of Bialystok and all patients submitted their consent in writing.
Statistical methods. Statistical analysis was performed with a statistics package Statistica 6.0 software (Statsoft, Cracow, Poland). Non-parametric U Mann-Whitney test was used. Results were expressed as mean SD. The $p$ values smaller than 0.05 were considered statistically significant. Bands intensity in blots were quantified using LabImage $1 \mathrm{D}$ gel software.

\section{Results \\ The different expression of TRAIL and DR5 in the lysates of PMN and PBMC}

Western blot analysis showed that the lysates of PMN and PBMC contained a $42 \mathrm{kDa}$ protein that was stained by an anti-TRAIL polyclonal antibody (Fig. 1). PMN and PBMC of whole cancer patient group expressed decreased TRAIL protein in comparison with the control group (Fig. 1). There were no significant differences in TRAIL expression between PMN and PBMC in patients as well as in the control group.

The presence of cellular DR5, a $58 \mathrm{kDa}$ protein, in PMN and PBMC lysates was confirmed using specific polyclonal antibody anti-DR5. There were no differences in expression of DR5 between cells of patients and the control group (Fig. 1). DR5 expression in 


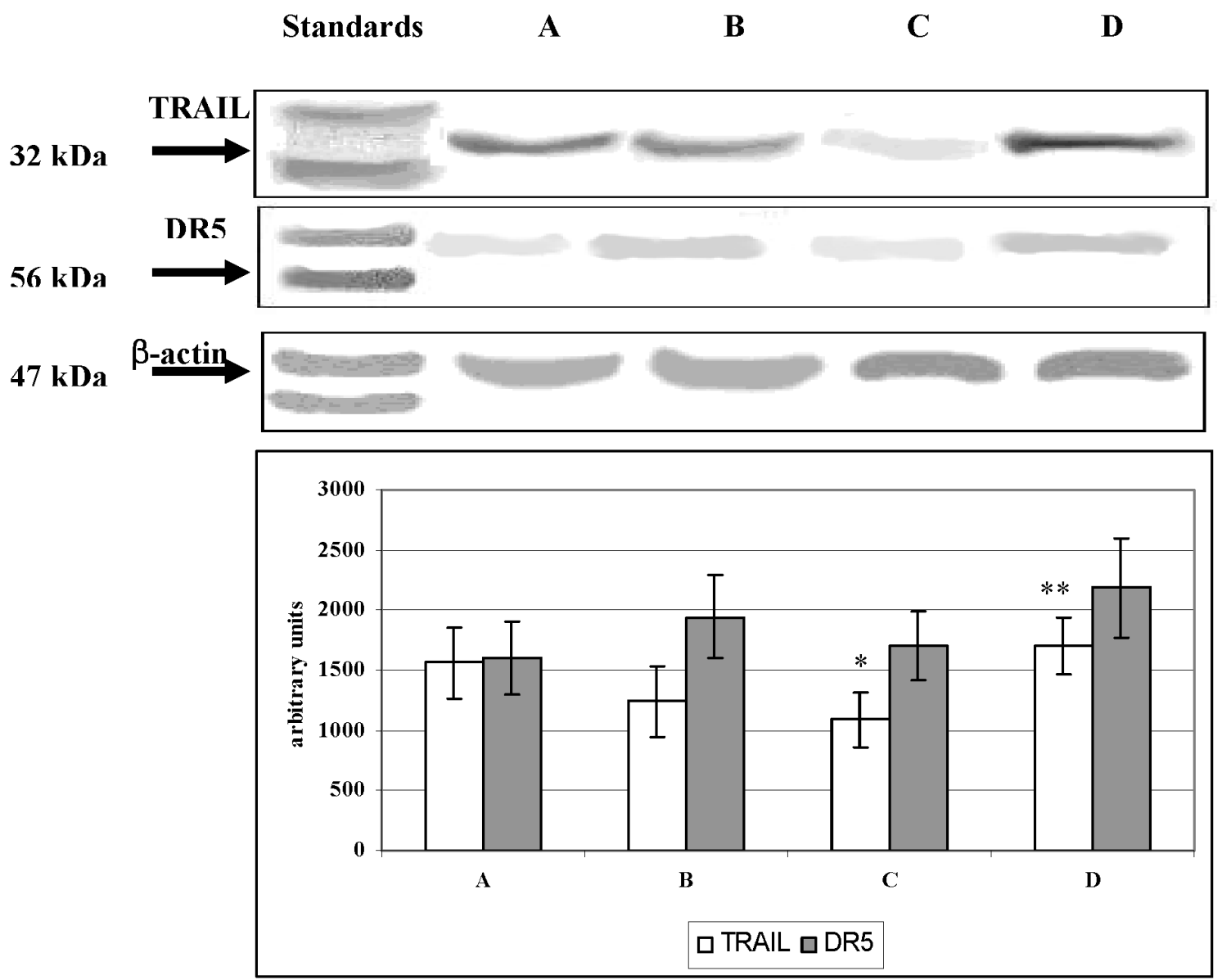

Fig. 2. Western blot analysis of TRAIL and DR5 protein expression in PMN and PBMC of cancer patients in Stage II. A: PMN from patients before treatment; B: PBMC from patients before treatment; C: PMN from patients after treatment; D: PBMC from patients after treatment. The diagrams are shown statistical analysis of Western blot of TRAIL and DR5 estimated by arbitrary units. astatistical difference with TRAIL expression before treatment $(\mathrm{p}<0.05)$; ${ }^{* *}$ statistical difference between PMN and PBMC after treatment $(\mathrm{p}<0.05)$.

PBMC of patients was higher as compared to its expression in PMN.

A comparison of the intensities of the bands corresponding to TRAIL in PMN and PBMC lysates derived from patients before and after treatment revealed a weaker expression of TRAIL in PMN of patients after treatment in comparison with its expression in examination before treatment (Fig. 2). Additionally, TRAIL expression protein in PBMC of patients after treatment was higher than in PMN. In contrast, DR5 expression in PMN and PBMC lysates was on the same level in patients before and after treatment.

\section{STRAIL and SDR5 concentrations in supernatants of cells and the serum}

The ELISA data showed no differences in the concentrations of sTRAIL in the culture supernatants of PMNs between all patients with oral cavity cancer and the healthy control (Table 1). Analysis of results according to TNM classification indicated that release of sTRAIL by PMN from cancer patients in Stage IV before surgery treatment was significantly lower in comparison with its release by cells from patients in Stage II and the control group. There were no differences in secretion of sTRAIL by PMN between patients in Stage II before treatment and the control. Examinations carried out in patients in Stage II after treatment showed insignificantly decreased secretion of sTRAIL by PMN and the same secretion of its by PMN from patients in Stage IV as compared to the studies before treatment (Table 1).

In contrast to PMN, PBMC from all patients before treatment, irrespective of clinical stage, secreted lower amounts of sTRAIL in comparison with the control group (Table 2). There were no differences in secretion of sTRAIL between patients in Stage II and in Stage IV. After treatment the changes in the concentrations of sTRAIL in the supernatants of PBMC from all patients were not significant.

In the present study the ability of PMN and PBMC of oral cavity cancer patients to release sDR5 receptor 
Table 1. The mean concentrations of sTRAIL and sDR5 in the culture supernatants of PMN from oral cavity cancer patients. *significant difference with the control $(p<0.05)$; ${ }^{a}$ significant difference between examinations before and after treatment $(p<0.05)$; ${ }^{b}$ significant differences between patients in Stage II and IV $(\mathrm{p}<0.05)$.

\begin{tabular}{|l|c|c|c|c|c|c|c|}
\hline \multirow{2}{*}{} & \multicolumn{9}{|c|}{ PMN } \\
\cline { 2 - 8 } & \multirow{2}{*}{$\begin{array}{c}\text { Control } \\
\mathrm{n}=15\end{array}$} & $\begin{array}{c}\text { Pll } \\
\text { patients } \\
n\end{array}$ & $\begin{array}{c}\text { Patients in } \\
\text { Stage II } \\
\mathrm{n}=16\end{array}$ & $\begin{array}{c}\text { Patients in } \\
\text { Stage IV } \\
\mathrm{n}=5\end{array}$ & $\begin{array}{c}\text { All } \\
\text { patients } \\
\mathrm{n}=21\end{array}$ & $\begin{array}{c}\text { Patients in } \\
\text { Stage II } \\
\mathrm{n}=16\end{array}$ & $\begin{array}{c}\text { Patients in } \\
\text { Stage IV } \\
\mathrm{n}=5\end{array}$ \\
\hline $\begin{array}{l}\mathrm{sTRAIL} \\
(\mathrm{pg} / \mathrm{m} 1 / 20 \mathrm{~h})\end{array}$ & $182 \pm 57$ & $167 \pm 64$ & $191 \pm 65$ & $107 \pm 53^{* \mathrm{~b}}$ & $121 \pm 38^{*}$ & $124 \pm 47^{* a}$ & $113 \pm 49^{*}$ \\
\hline $\begin{array}{l}\mathrm{sDR} 5 \\
(\mathrm{pg} / \mathrm{ml} / 20 \mathrm{~h})\end{array}$ & $24.3 \pm 8.3$ & $21.4 \pm 9.9$ & $20.3 \pm 8.6$ & $26.2 \pm 11.4$ & $22.7 \pm 10.9$ & $21.3 \pm 10.2$ & $24.5 \pm 12.3$ \\
\hline
\end{tabular}

Table 2. The mean concentrations of sTRAIL and sDR5 in the culture supernatants of PBMC from oral cavity cancer patients. *significant difference with the control $(\mathrm{p}<0.05)$.

\begin{tabular}{|l|c|c|c|c|c|c|c|}
\hline \multirow{2}{*}{} & \multicolumn{9}{|c|}{ PBMC } \\
\cline { 2 - 8 } & \multirow{2}{*}{$\begin{array}{c}\text { Control } \\
\mathrm{n}=15\end{array}$} & $\begin{array}{c}\text { All } \\
\text { patients } \\
\mathrm{n}=21\end{array}$ & $\begin{array}{c}\text { Patients in } \\
\text { Stage II } \\
\mathrm{n}=16\end{array}$ & $\begin{array}{c}\text { Patients in } \\
\text { Stage IV } \\
\mathrm{n}=5\end{array}$ & $\begin{array}{c}\text { All } \\
\text { patients } \\
\mathrm{n}=21\end{array}$ & $\begin{array}{c}\text { Patients in } \\
\text { Stage II } \\
\mathrm{n}=16\end{array}$ & $\begin{array}{c}\text { Patients in } \\
\text { Stage IV } \\
\mathrm{n}=5\end{array}$ \\
\hline $\begin{array}{l}\text { sTRAIL } \\
(\mathrm{pg} / \mathrm{ml} / 20 \mathrm{~h})\end{array}$ & $178 \pm 64$ & $116 \pm 49^{*}$ & $106 \pm 47^{*}$ & $100 \pm 52^{*}$ & $151 \pm 60$ & $150 \pm 71$ & $153 \pm 68$ \\
\hline $\begin{array}{l}\mathrm{sDR} 5 \\
(\mathrm{pg} / \mathrm{ml} / 20 \mathrm{~h})\end{array}$ & $24.3 \pm 8.3$ & $21.9 \pm 10.2$ & $22.3 \pm 9.2$ & $25.8 \pm 12.5$ & $24.6+13.1$ & $24.7 \pm 11.1$ & $23.0 \pm 11.6$ \\
\hline
\end{tabular}

Table 3. Serum concentrations of sTRAIL and sDR5 in patients with oral cavity cancer and control group. *significant difference with the control $(\mathrm{p}<0.05)$; ${ }^{\text {a }}$ ignificant difference between examinations before and after treatment $(\mathrm{p}<0.05)$.

\begin{tabular}{|l|c|c|c|c|c|c|c|}
\hline \multirow{2}{*}{} & \multicolumn{9}{|c|}{ Serum } \\
\cline { 2 - 8 } & \multirow{2}{*}{$\begin{array}{c}\text { Control } \\
\mathrm{n}=15\end{array}$} & $\begin{array}{c}\text { Pll } \\
\text { patients } \\
\mathrm{n}=21\end{array}$ & $\begin{array}{c}\text { Patients in } \\
\text { Stage II } \\
\mathrm{n}=16\end{array}$ & $\begin{array}{c}\text { Patients in } \\
\text { Stage IV } \\
\mathrm{n}=5\end{array}$ & $\begin{array}{c}\text { All } \\
\text { patients } \\
\mathrm{n}=21\end{array}$ & $\begin{array}{c}\text { Patients in } \\
\text { Stage II } \\
\mathrm{n}=16\end{array}$ & $\begin{array}{c}\text { Patients in } \\
\text { Stage IV } \\
\mathrm{n}=5\end{array}$ \\
\hline $\begin{array}{l}\text { sTRAIL } \\
\text { (pg/m1) }\end{array}$ & $319 \pm 108$ & $407 \pm 132$ & $439 \pm 167^{*}$ & $378 \pm 138$ & $268 \pm 143^{\mathrm{a}}$ & $277 \pm 123^{\mathrm{a}}$ & $248 \pm 131$ \\
\hline $\begin{array}{l}\text { SDR5 } \\
(\mathrm{pg} / \mathrm{ml})\end{array}$ & $18.6 \pm 7.9$ & $21.9 \pm 10.2$ & $20.5 \pm 10.2$ & $22.4 \pm 12.5$ & $30.5 \pm 16.2^{*}$ & $26.0 \pm 11.1$ & $38.0 \pm 16.2$ \\
\hline
\end{tabular}

was also examined. However, we did not find any differences between the concentrations of sDR5 in the culture supernatants of patient cells and the control cells (Table 1 and 2).

The concentrations of STRAIL and sDR5 in the culture supernatants of PMN and PBMC were confronted with their serum levels. Soluble TRAIL concentrations in the serum of all cancer patients before treatment were not different from the concentrations in the control group (Table 3). However, the concentration of sTRAIL in the serum of patients in Stage
II was higher in comparison to the control group. After treatment, the serum levels sTRAIL in all patients were significantly lower as compared to the values obtained in examination before treatment.

In contrast to sTRAIL, there were no differences in the serum sDR5 concentrations between the patients and the control group (Table 3).

There were no correlations between the serum levels of sTRAIL and SDR5 and their concentrations in the culture supernatants of PMN or PBMC. 


\section{Discussion}

The role of human neutrophils in TRAIL-mediated reactions was confirmed by Tecchio et al. who showed that these cells releasing sTRAIL exhibit proapoptotic activities towards TRAIL-sensitive chronic myeloid leukemic cell lines [6]. Furthermore, Koga et al. reported that when Jurkat cells, a well-known leukemic cell line susceptible to TRAIL-mediated killing, were cultured with neutrophils in the presence of IFN- $\gamma$, the number of Jurkat cells undergoing apoptosis increased [18].

In the present study we demonstrated an interesting relation between the ability of PMNs and autologous PBMC to the secretion of sTRAIL in oral cavity cancer patients. Unchanged release sTRAIL by PMNs of patients in Stage II was accompaying the decrease of the ability of PBMC to the secrete of this protein. Since during the growing phase tumors are infiltrated first by neutrophils, then macrophages and T cells, retained secretion of sTRAIL by PMNs in the microenvironment of tumor can lead to the TRAILmediated apoptosis of cancer cells at early phase of disease [19]. Its observation appears as especially important, particularly in the light of the fact that primary oral squamous carcinoma cells are more susceptible to TRAIL as compared to the metastatic carcinoma cells [20].

The unchanged secretion of sTRAIL by PMN of patients with oral cavity cancer in Stage II may be one of mechanisms responsible for decreased in secretion of sTRAIL by autologous PBMC observed in the present study. It was well established that apart from its ability to provoke apoptosis: TRAIL was shown to inhibit $\mathrm{T}$ cell activation and proliferation without inducing T-cell death [7]. Thus, despite of retained secretion of sTRAIL by PMN, simultaneously decreased secretion of its by PBMC can be insufficient for activity of this protein in patients with oral cavity cancer.

It is interesting to note that the secretion of sTRAIL by both kind of cells in patients in Stage IV was impaired, suggesting a significant defect not only PBMC but also PMN. It is possible that observed changes are associated with direct or indirect activity of the tumor cells. Results obtained after surgery treatment suggest a different effect of tumor cells on the activity of PMN and PBMC. The defect PMN of cancer patients associated with sTRAIL secretion appears to be more lasting than that observed in PBMC.

Changed secretion of sTRAIL by both kind of leukocytes may play a different role in modulating leukocyte/endothelial cell adhesion. Recently, Secchiero et al. demonstrated that TRAIL has a potential anti-adhesive effect and that this activity is mediated by the selective down-regulation of chemokines CCL8 and CXCL10 [21].
The insufficient secretion of sTRAIL by examined leukocytes, observed in the present study particularly in patients with advanced disease, may promote the neoangiogenesis. Cantarella et al. demonstrated that TRAIL inhibits angiogenesis stimulated by VEGF [22]. Our previous study on this patient group indicated a high production of VEGF by PMN and markedly elevated serum levels of its [23].

In contrast to changes in STRAIL secretion by PMN and PBMC of oral cavity cancer patients, the secretion of sDR5 by these cells was unchanged. The lack of changes in the secretion of this inhibitory protein for TRAIL may be a protective mechanism against insufficient secretion of its by leukocytes. Our previous study in this patients showed a diverse relation between the TNF- $\alpha$, a prototype member of TNF family and its soluble receptor sTNF-Rp75 which play a regulatory role in TNF- $\alpha$-mediated reactions [24]. In the culture supernatants of PMN high TNF- $\alpha$ concentrations were accompanying the increased concentrations of sTNFRp75. The excess of TNF- $\alpha$ may balance the deficit of TRAIL secretion by PMN of examined patient group. However, the presence of its inhibitory protein may reduce the TNF activity. Broader prospective studies are required to explain of this problem. However, our observations suggest that the estimation of cytokine secretion should be associated with simultaneous estimation of their soluble regulatory proteins.

It is necessary to note that the changes in the secretion of sTRAIL by PMN and PBMC of patients with oral cavity cancer were not associated with changes in its serum levels. The lack of such dependence suggest that other cells, such as cancer cells, may account for sTRAIL concentrations in the blood. Studies of Teng et al. demonstrated that HNSCC cells, involving oral cavity cancer cells, have ability to secrete TRAIL ligand that activates TRAIL receptors [16]. The decreased serum levels of sTRAIL in patients after surgery treatment observed in these examinations appear to confirm role of cancer cells in the secretion of this protein.

In conclusion, changed activity of PMN and of PBMC associated with secretion of sTRAIL may have different implications for the immune response of patients with oral cavity cancer cells at different stages of disease. The lack of changes in sTRAIL secretion by PMN in patients at early phase of disease may have a favorable effect on the anti-tumor response. The low secretion of sTRAIL by both kind of cells in patients with advanced disease suggests introducing an immunotherapy modulating these cells for enhanced secretion of TRAIL or a therapy with exogenous TRAIL.

Furthermore, since TRAIL/TRAIL-R system may contribute to the fate of tissue-infiltrating neutrophils and mononuclear cells, the lack of changes in expres- 
sion of death receptor DR5 make them sensitive to TRAIL-mediated apoptosis-induced by cancer cells that is responsible for the impaired activity of these leukocytes in oral cavity cancer patients.

\section{References}

[1] Cassatella MA. The production of cytokines by polymorphonuclear neutrophils. Immunol Today. 1995;16:21-6.

[2] Di Carlo E, Forni G, Lollini P, Colombo MP, Modesti A, Musiani P. The intriguing role of polymorphonuclear neutrophils in antitumor reactions. Blood. 2001;97:339-345.

[3] Szymkowiak ChH, Csernok E, Reinhold D, Bank U, Gross WL, Kekow J. Neutrophils synthesize and activate TGF $\beta 2$. Cytokine. 2000;12:397-400.

[4] Kamohara H, Matsuyama W, Shimozato O, Abe K, Galligan C, Hashimoto S, Matsushima K, Yoshimura T. Regulation of tumour necrosis factor-related apoptosis-inducing ligand (TRAIL) and TRAIL receptor expression in human neutrophils. Immunology. 2004;111:186-194.

[ 5] Scapini P, Nardelli B, Nadali G, Calzetti F, Pizzolo G, Montecucco C, Cassatella MA. G-CSF-stimulated neutrophils are a prominent source of functional BLyS. $J$ Exp Med. 2003;197: 297-302.

[ 6] Tecchio C, Huber V, Scapini P, Calzetti F, Margotto D, Todeschini $\mathrm{G}$, et al. IFN $\alpha$-stimulated neutrophils and monocytes release a soluble form of TNF-related apoptosis-inducing ligand (TRAIL/Apo-2 ligand) displaying apoptotic activity on leukemic cells. Blood. 2004;103:3837-3844.

[7] Ehrlich S, Infante-Duarte C, Seeger B, Zipp F. Regulation of soluble and surface-bound TRAIL in human T cells, B cells, and monocytes. Cytokine. 2003;24:244-253.

[ 8] Almasan A, Ashkenazi A. Apo2L/TRAIL: apoptosis signaling, biology, and potential for cancer therapy. Cytokine Growth Factor Rev. 2003;14:337-348.

[9] Griffith TS, Lynch DH. TRAIL: a molecule with multiple receptors and control mechanisms. Curr Opin Immunol. 1998; 10:559-563.

[10] MacFarlane M. TRAIL-induced signalling and apoptosis. Toxicol Lett. 2003;139:89-97.

[11] Emery JG, McDonnell P, Burke MB, Deen KC, Lyn S, Silverman $\mathrm{C}$, et al. Osteoprotegerin is a receptor for the cytotoxic ligand TRAIL. J Biol Chem. 1998;273:14363-14367.

[12] Lee HW, Lee SH, Lee HW, Ryu YW, Kwon MH, Kim YS Himomeric and heteromeric interactions of the extracellular domains of death receptors and death decoy receptors. Biochem Biophys Res Com. 2005;330:1205-1212.

[13] Miyashita T, Kawakami A, Kanshima T, Yamasaki S, Tamai M, Tanak A, et al.. Osteoprotegerin (OPG) acts as an endoge- nous decoy receptor in tumour necrosis factor-related apoptosis-inducing ligand (TRAIL)-mediated apoptosis of fibroblast-like synovial cells. Clin Exp Immuno. 2004,137:430-436.

[14] Liang X, Liu Y, Zhang Q, Gao L, Han L, Ma Ch, Zhang L, Chen YH, Sun W. Hepatitis B virus sensitizes hepatocytes to TRAIL-induced apoptosis through Bax. J Immuno. 2007;178: 503-510.

[15] Younes A, Kadin ME. Emerging applications of the tumor necrosis factor family of ligands and receptors in cancer therapy. J Clin Oncol. 2003;21:3526-3534.

[16] Teng MS, Brandwein-Gensler MS, Teixeira MS, Martignetti JA, Duffey DC. A study of TRAIL receptors in squamous cell carcinoma of the head and neck. Arch Otolaryngol Head Neck Surg. 2005;131: 407-412.

[17] Sobin LH, Wittekind C. UICC TNM classification of malignant tumours, $5^{\text {th }}$ ed. Berlin, Springer 1997.

[18] Koga Y, Matsuzaki A, Suminoe A, Hattori H, Hara T. Neutrophil-derived TNF-related apoptosis-inducing ligand (TRAIL): a novel mechanism of antitumor effect by neutrophils. Cancer Res. 2004;64:1037-1043.

[19] Stoppacciaro A, Melani C, Parenza M, Mastracchio A, Bassi $\mathrm{C}$, et al. Regression of an established tumor genetically modified to release granulocyte colony-stimulating factor requires granulocyte - T cell cooperation and T cell - produced interferon gamma. $J$ Exp Med. 1993;178:151-161.

[20] Nagaraj NS, Vigneswaran N, Zacharias W. Cathepsin B mediates TRAIL-induced apoptosis in oral cancer cells. J Cancer Res Clin Oncol. 2006;132:171-183.

[21] Secchiero P, Corallini F, Jasio MG, Gonelli A, Barbotto E, Zauli G. TRAIL counteracts the proadhesive activity of inflammatory cytokinez In endothelial cells by down-modulating CCL8 and CXCL10 chemokine expression and release. Blood. 2005;105:3413-3419.

[22] Cantarella G, Risuglia N, Dell'eva R, Lempereur L, Albini A, Pennisi G, Scoto GM, Noonan DN, Bernardini R. TRAIL inhibits angiogenesis stimulated by VEGF expression in human glioblastoma cells. British J Can. 2006;94:1428-1435.

[23] Jablonska E, Puzewska W, Grabowska Z, Jablonski J, Talarek L. VEGF, IL-18 and NO production by neutrophils and their serum levels In patients with oral cavity cancer. Cytokine. 2005;30:93-99.

[24] Jablonska E, Kiluk M, Piotrowski L, Grabowska Z, Markiewicz W, Jablonski J. Tumor necrosis factor-alpha and soluble tumor necrosis factor receptors In the culture supernatants of polymorphonuclear cells and peripheral blond mononuclear cells from cancer patients. Eur Cytokine Netw. 1998;9:155-159.

Submitted: 27 August, 2007 Accepted after reviews: 12 December, 2007 